\title{
Figurative Language In Kelly Darrow's Selected Poetry
}

\author{
Cicih Nuraeni ${ }^{1}$, Putri Amalia Peron ${ }^{2}$ \\ ${ }^{1}$ Sastra Inggris \\ Sekolah Tinggi Ilmu Bahasa Asing Nusa Mandiri \\ Jl. Ir. H. Juanda No. 39 Ciputat \\ cicih@nusamandiri.ac.id \\ ${ }^{2}$ Bahasa Inggris \\ Akademi Bahasa Asing BSI Jakarta \\ Jl. Salemba Tengah N0. 45 Jakarta Pusat \\ putriamaliaperon@gmail.com
}

\begin{abstract}
This research has the objectives proposed by the writers, they are: (1) To identify the types of figurative language used in Kelly Darrow's selected poetry, (2) to find out the meaning of figurative language used in Kelly Darrow's selected poetry, and (3) to know the mostly of figurative language that is used in Kelly Darrow's selected poetry in this research. The title of the selected poetry area Charm of Cobra, Politicians and The Black Cape. Figurative language is one of the elements of poetry that has become the poets' way of expressing the art of his poetry and communicating his language to know the poet's idea. Figurative language can include many words and phrases, and there are several types of figurative language. The primary sources of data are the research is conducted by using descriptive qualitative method. The data sources of this research are taken from the poetry by Kelly Darrow. Then the writers classify the data using McKenzie's theory of figurative language that support it. The results of this paper shows there are many types of figurative language in Kelly Darrow's selected poetry. Kelly Darrow uses metaphor, simile, irony, personification, and hyperbole as figurative language.
\end{abstract}

Keywords: Poetry; Figurative Language; Kelly Darrow’s.

\section{INTRODUCTION}

Literature is a literary work which there is a beautiful art that comes from human life. Literary work is the result of the expression of feelings and describes imagination of the author. Literature is a description of human experience that has personal and social dimension and the knowledge of humanity that equal with the shape of life itself. Literature is a permanent expression in words of some thoughts or feeling or idea about life and the world. Literature as the language art has become the media to express people mind. This shows that literary work has strong correlation with the reflection of people's life and social life.

The main generic of literature today is novel, drama, and poetry. Poetry is kinds of literature which is written form of lines, stanzas, style, and pattern. Poetry is a universal language used by the poets to express their ideas in beautiful words. As a universal language, poetry has existed almost in all period. Poetry might be defined as a kind of language that says more and says it more intensely than ordinary language. Language used by a poet as a tool to deliver a meaning particularly. The purpose of poetry is to entertain, critic, or persuade.

Poetry is difficult to be understood, to some people when studying or reading poetry. This is because the power of language in poetry is arranged by concentration of physical and mental structures that contain very deep meanings. When readers read poetry, they can find the figurative language used in the poetry. Figurative language is not to make poetry confusing, but it is aim to make it clear. It also to sharpen the perception as a reader and to permit a fuller understanding of what it is in a poetry that gives pleasure and creates form and meaning.

Poetry is one of the literary work in which special intensity is given to the expression of feelings and ideas through meaning, sound, rhythmic language choices so as to evoke an emotional response. Robert Frost as cited in Kennedy (2007:656), "Poetry is a rhythmical composition of words expressing attitude, design to surprise and delight and to arouse an emotional response”. It deals with emotion and presents the emotions of the poet as they are aroused by some scene, some experience and some attachment. Wordsworth as cited in Robinson (2010:26) says that "Poetry is the spontaneous overflow of powerful feeling, expression of emotion and it is always concerned with ordinary human concerns, with the daily matters of one's life”. It means that, poetry is the express of author feeling and thought based on the author mood experiences and imaginative and use spontaneous expression. Poetry flows out of his heart in a natural and fluent manner. Deep emotion is the basic condition of poetry; powerful 
feelings and emotions are fundamental, without them great poetry cannot be written.

Based on the definition above, the writers concludes that poetry is a media that used by human to express their ideas, feeling and experiences. Poets project their emotion, thoughts, and ideas to their readers and poetry also in an arrangement of words expresses someone's feeling and happiness or sadness spontaneously. In other words, poetry is usually expressed based on author imagination. The important thing is that the image an instrument that a poet uses to express the author intention or feeling.

Some literatures use figurative language to make it more interesting, as it is used in poetry lyric. Poetry lyrics are some informative literature that gives information with literal meaning using figurative language. Thus to understand it, people have to think deeper. There are difficult vocabularies in the lyric, people must explain or give special attention to giving meaning. To understand the lyric, it is important to know and found the meaning of figurative language used in the lyric of poetry.

In expressing or describing something, an author conveys a way that is different. An author in conveying feelings and thoughts also uses language in different way too. It makes expression of varied thoughts and feelings. Variations in the use of the word, the wording or language, are called figurative language. McKenzie (2016: 66) states that "Figurative Language refers to language that communicates ideas beyond the literal meaning of word". In other words, figurative language makes writing concrete, because language is adaptable and lends itself to imaginative usage. The author can express the same idea in different ways. They may use direct statement or figurative language. Dancygier and Sweetser also (2014:1) states that "Figurative language was thought of as being one aspect of what gives a textin particular, a poetic text-special esthetic value". It means that figurative language is expressing something that used in any text, especially in a poetic text to refer one thing by giving the implied meaning. It is often used in literary work to demonstrate the creativity of the author and the beauty language itself.

According to Tjahjono (2011:54) "Figurative language is one of the important elements to writes poetry”. In writing poetry using figurative language so that it can be more beautiful language in poetry, the poet must choose appropriate the word that be able to describe something clearly in the readers mind. Perrine, In Arp (2000:68) states that "Figurative language is the language that cannot be taken literally (or should not to be taken literally only) and saying something other than ordinary way or a way of saying one thing and meaning another”. Based on Perrine perception, so we can say more by these figurative statement rather than literal statement. Figure of speech offers another way of adding extra dimension to language.

Peterson (2012: 16) defines that "Figurative language is to say something that actually means something else". What is being said is not to be taken literary. It deals, using figurative language to enhance the emotional intensity and imaginative appeal of poetry, the poet can convey so much more than through literal language alone.

The purpose of figurative use in poetry is to stimulate a certain image. It affects the language beauty of work in both oral and written communication. Figurative language serves a variety of purposes. They are used to clarify meaning, to provide vivid examples, to emphasize, to stimulate associations and emotions, to give a life to inanimate object, to amuse or to ornament. The most importance, they have an essentials aesthetic purpose, widening and deepening the range of perception and response to the word of objects and ideas. In other words, figurative language serves to convey thoughts, feelings, and perceptions that cannot be adequately expressed in literal language.

Therefore the writers found the proper strategy to analyze poetry. It is expected that the reader will understand and comprehend the meaning of poetry. The poetry that the writers would like to analyze is literary works by Kelly Darrow. Kelly Darrow poetry is describe about love, desire, and a little strangeness especially about human life and theme of his works content social and philosophical values.

In this study, the writers found interesting to analyze Kelly Darrow's selected poetry. The purpose of this research is to increase the reader's knowledge about literary particularly in poetry and to provide accurate information especially to understand the meaning about figurative language in poetry by Kelly Darrow.

\section{RESEARCH METHODOLOGY}

The writers use descriptive qualitative method to analyze this study. According to Moleong (2007: 3) "Descriptive research is a type of research which does not use calculation or numerating. This method is implemented to reach the objectives of the study”. It can be seen that the writers intend to observe the analysis process. The main technique to collect the data is observation where the research of observe the object directly in order to get the real data from the field where the object exists. To describe the process, the writers use his own instrument, so that the results might be subjective.

The first procedures are taken by the writers is reading to the poetry. The second, the writers are trying to understand the story of the poetry. Third is choosing the theory that suitable with the analysis. After that, the writers look for data from library, internet, and reads kinds of books which are related to the title. Then, the writers analysis the poetry and relates the theory to the poetry. After all of procedures are arranged then the writers make conclusion from the analysis. 


\section{RESULT AND DISSCUSSION}

A. Summary of the Poetry that Selected

\section{Charm of Cobra}

\section{She has the sting of a scorpion, and the charm of a cobra}

She acts like your friend, but she don't know ya

She slithers through the grass straight to your heart

Leaves you wondering how did this all start?

She's slick as they come, she'll destroy ya

Master of the tongue, but never annoys ya

Her bite is sexy, just before the poison

So peaceful, she makes you feel like the chosen

She has many lovers, but she's your only one You're free to leave, but she knows you'll never run

Her manipulation leads to your destruction

The mastery of her art, is the beauty of her seduction

You end up giving her your life and soul

In return, she leaves you a six foot whole

Her job is complete; she slithers away in perfect rhythm

Leaving your hole to find her next victim

"Charm of Cobra" is one of Kelly Darrow poetry. This poetry was published in 2012. This poetry consist four stanzas of four lines each. Charm of Cobra by Kelly Darrow is poetry that portrays a huge meaning to his readers. This poetry is written by the narrator relates with his own experience as a Licensed Alcohol and Drug Abuse Counselor. From all of the explanation, the writers conclude that the narrator has inspired to write the poetry about drug, but the narrator make comparison in this poetry with cobra.

The narrator talk about cobra has poison, sting, and it can catch the victim. Next, the narrator says that her bite is sexy, just before the poison. It means that same as with drug, to some people who is suffering from depression or other mental illnesses use drugs to ease their suffering, and to relieve the pain. They think drugs can temporary make them feel so peaceful even though it can kill them. Through literary devices, Darrow reveals what will ultimately bring the drugs abuser. $\mathrm{He}$ provides us with the ways that drugs itself for influencing the people.

\section{Politicians}

Politicians promising through their lips Issues and answers

Giving us all the lip
Spreading to the people like cancers

\section{Crooked suits on the hill \\ Homeless in the street \\ Doctor's and their pills \\ Working man dead on his feet}

\section{Soldiers injured and dying ever day}

In the dirt and dust

They come back and their VA benefits won't pay

And in the Government we supposed to trust?

Politicians holding out their hand

For the blue collar to shake

In this free land

Politicians smile is fake

Politician man

Who are you?

Do you think you ever can?

Be a better man?

Government run cooperation's

So corrupt in their nature of operations

They make quick alterations

To avoid incarceration
This poetry consists six stanzas of four lines each. The narrator purpose in writing his literary work is to criticise politicians and their reputation. The narrator describes about politicians who has be more sweetmouthed in saying their promises, especially they have a lot of promises on their campaign process. they are obviously lying. They still doing to deviant ways, they began to erode with the habit of bad behavior by those who think only about their own interest and their group.

In the modern era, democracy in order to get power or to stay in power a politician needs to lie about his or her intentions, needs to maneuver and disorient enemies from the opposition and frequently from his own party or has to keep his or her mouth shut and keep a straight face although there is much to say.

In the last point in the lyric of this poetry. The narrator says that government run corporation with their political party to corruption, and they make shield with behind the habit of bad behavior by these who think only about their interest and their group.

\section{The Black Cape}

I wear pain like a black cape,

I carry it like clouds carry rain. It disappears with your touch whispering itself away like sand in the wind. I'm no stranger to the pain It's a feeling that's all too familiar, so dust of your boots 
and I'll try on my funeral suit.

My thoughts no longer clear

so let me whisper something to you

before I go, I want you to know

I love you.

Before darkness takes over my brain

and I feel the numbness,

I pray so hard

to feel the softness of your hand.

On this morning-the sun so high

nothin much left to do but lay here.

On this dreaded morning before I go

I don't want any sadness on your face.

My thoughts no longer make since,

I am no longer.

No longer do I show the life.

One last time before I close my watering eyes

I want to hold your hand

and see your smile

as I caress your pretty hair.

Time is short, the black cape's comin again.

I pray to see the light

shining at the end

and after your long life- to hold you tight.

This pretty poetry is a story about pain. Everyone has problems in their life. It deals that problem become more difficult when there is no obvious solution, it makes feel so pain.

From the all of this poetry lirycs, the writers conclude that there is a man who is on a journey to find peace in his mundane life. He had the misfortune of waking up in terrific pain. He fells worse than the pain was the dark, like black cloud that constantly loomed over him. He thought he was losing his mind, he get depression. It felt as if he was imprisoned in his own body, he had no interest in anything except the dark cloud.

The lyric of "and I'll try on my funeral suit" define that he want to die, and it usually comes up when people are in so much psychological pain that they feel they can no longer bear it. This pain is often made worse by thoughts of being a burden to others or not belonging anywhere because he had a very small glimpse of what it is like to live with depression. There are days of horrible, and unreasonable thoughts. The world has a dark filter on it, and everything seems difficult.

The narrator describes, he wants to giving up on his life but he fortunate to have a partner who is understanding him. From this lyric also there is a girl who always been there for him. All the pain is disappear when he feels a touch of the girl.

\section{B. Analysis}

\section{Poet 1 - Charm of Cobra}

Table 1 of "Charm of Cobra”

\begin{tabular}{|c|l|c|}
\hline No & Lyrics & Stanza \\
\hline \multirow{1}{*}{1} & $\begin{array}{c}\text { She has the sting of a scorpion, and the } \\
\text { charm of a cobra }\end{array}$ & 1 \\
\cline { 2 - 3 } & $\begin{array}{c}\text { She acts like your friend, but she don't } \\
\text { know ya }\end{array}$ & 1 \\
\cline { 2 - 3 } & $\begin{array}{c}\text { Her bite is sexy, just before the poison } \\
\text { The mastery of her art, is the beauty of } \\
\text { her seduction }\end{array}$ & 2 \\
\cline { 2 - 3 } & $\begin{array}{c}\text { You end up giving her your life and soul } \\
\end{array}$ & 3 \\
\hline
\end{tabular}

\section{Data I}

Lyric the charm of a cobra

Result : Metaphor

From the lyrics above,the first thing to know is that this poetry is about drug. Based on McKenzie's theory metaphor compares two unlike thing without using words like or as. The narrator comparing two things of the phrase "the sting of scorpion" compared to the harmful of drug, and "the charm of cobra" as the shape of drug itself. Some people think, when they are getting depression, they are interested to use drugs because it has also the charm. As far as we know that some people have extreme desire to obtain and use drugs. They think drugs are a solution, but eventually the drugs become the problem. The writers conclude that in this poetry stanza 1 and line 1 is metaphor.

\section{Data II}

Lyric : She acts like your friend, but she don't know ya

Result : Simile

The writers identify those lines as simile because the narrator compares between a cobra and a friend, and the phrases also uses connectives "like". The phrase says that cobra is his friend. It does not mean cobra can accompany him, cobra can spending time together, or treat him well like a friend in our reality life.

Based on the analyze by the writers in the previous explanation "cobra" is referred to drugs. It shows some people take drugs because they want to change something about their lives, drugs can give them euphoria without society. Drug abuser gets lost a lot of families and friends, they think with drugs is enough to doing their life.

Drug abuser has consumed a large portion of their time, making obtaining drugs and using their top priority. Their relationships are beginning to grow apart 
because they have been putting drugs ahead of their family or friends. It is clearly from the narrator to compare"cobra" (drugs) acts like friend.

\section{Data III}

Lyric

poison

Result

: Her bite is sexy, just before the

From the lyric above, the narrator creates an ironical sentence. Based on McKenzie states that irony is the opposite of what one means.

The first statement is her bite is sexy, the second statement is before a poison. Thus phrase talks about drugs are essentially poisons. In the next sentences the narrator says that "So peaceful, she makes you feel like the chosen". It means, they think drugs can temporary make them feel so peaceful. The amount taken determines the effect. A small amount acts as a stimulant (speeds drugs abuser up). A greater amount acts as a sedative. An even larger amount poisons and it can kill them.

\section{Data IV}

\section{Lyric} of her seduction

Result : Metaphor

The use of the mastery of art as the characteristic drugs can distort the user's perception of what is happening around him or her. For seduction, the narrator writes this poetry from the perspective of drugs itself that can make the people who is obsessed to try and have to desire to consume them.

The narrator also explain in the previous sentence Her manipulation leads to your destruction. It means that drugs can be manipulative, because drugs can create destruction in all areas of your life. That makes the lyrics are categorized as metaphor.

\section{Data V}

$\begin{array}{ll}\text { Lyric } & \text { :You end up giving her your life and } \\ \text { soul } & \text { : hyperbole }\end{array}$

The narrator creates hyperbole in this lyric. According to McKenzie states that hyperbole/ overstatement is figure of speech that uses exaggeration and humor to emphasize the magnitude of thing, such as size, feeling, or reaction. The phrase above contain exaggeration of reaction.

This lyric tells about drug abuser can give the whole of their life, even they want to do everything to get drugs. Addiction can cause a great financing issue in the lives of the addict themselves, as well as their family members. They have been spending any money to get more drugs..

The final danger of addiction is the loss of self. They can lose their self by destroying health, by abandoning personal relationships and by giving up their dreams for the sake of drugs. After the drugs of abuse have been giving the everything they have instead, drugs can damage life, health and even it kill the users.

Poet 2 - Politician

Table 2 of "Politician

\begin{tabular}{|c|c|c|}
\hline No & Lyrics & Stanza \\
\hline \multirow{4}{*}{1} & $\begin{array}{c}\text { Spreading to the people like } \\
\text { cancers }\end{array}$ & 1 \\
\cline { 2 - 3 } & Crooked suits on the hill & 2 \\
\cline { 2 - 3 } & Homeless in the street & 2 \\
\cline { 2 - 3 } & Doctor's and their pills & 2 \\
\cline { 2 - 3 } & Working man dead on his feet & 2 \\
\cline { 2 - 3 } & Soldiers injured and dying everyday & 3 \\
\hline
\end{tabular}

\section{Data I}

Lyric

lips

$\begin{array}{ll} & \text { Issues and answers } \\ & \text { Giving us all the lip } \\ & \text { Spreading to the people like cancers } \\ \text { Result } & \text { : Simile }\end{array}$

In the first stanza the poetry begins with a criticism of the politicians. The lyric is using simile. There is a comparison between an action of politician promises and a cancer. It means politicians has be more sweet-mouthed in saying their promises.

The narrator says that politicians promises is spreading like cancers, as far as we know that cancers is a dangerous disease and it can spread quickly. The meaning of figurative language that contained in these lyrics is the broken promises of politicians. It likes cancer means that every part of their promises usually it nonsense.

So, the writers conclude that this lyric contain the type of figurative language that is simile, because of the lyric is using the connective "like".

\section{Data II \\ Lyric \\ Result \\ : Crooked suits on the hill \\ : Understatement.}

The meaning of the lyric "Crooked suits" is characteristic of politicians that has a big lies and "on the hill” it means a high position in government. The narrator wants to describe about to be a politicians that has high position in government. They mostly have a big lies, they only think about they private needs, they are really ingratitude.

From lyric above, the narrator make an understatement deliberately makes a situation seem less important or serious than it is. This can be done for simply to be polite. So, the writers finding this lyric is understatement as type of figurative language.

\section{Data III \\ Lyric \\ Result

\author{
: Homeless in the street
} \\ : Metaphor}


In the lyric above, the narrator uses metaphor. He compares politicians with a homeless. It is an implied comparison because the comparison of two unrelated things essentially unlike here. It is drawn without the use of connective word.

The meaning of this lyric is when we think of homeless, the first image that usually comes to mind is that of the beggars walking around looking for charity. In the other side, some people think that politicians same as homeless because they always looking for sympathy to get what they want, especially in politic process.

\section{Data IV}

$\begin{array}{ll}\text { Lyric } & \text { : Doctor's and their pills } \\ \text { Result } & \text { : Metaphor }\end{array}$

In this lyric the writers found as metaphor because there are comparison two unlike thing. The meaning of this lyric is can be conclude that if the doctor can be healing the disease with their pills. Then, this is comparable to a politician who have unveiled fresh pledges, he claim that with his promises can handle all the problems that exist in his country.

\section{Data V}

\section{Lyric Result \\ : Working man dead on his feet : Hyperbole}

In this lyric, hyperbole is language style using a gross exaggeration of the fact. Exaggeration is used to create a strong effect. There are exaggerations involved in these lyrics, exaggerations that might be possible to do but it is impossible condition

The lyric of Working man dead on his feet. It does not mean the man death while he is working. This lyric is telling about the man who working hard in politic as supporting the candidates of politic who is want to get high position in government. In this case, the writers give example, usually in a political party there is a successful team who are willing to work hard in order to win election from their candidates to become politicians

\section{Data VI}

\section{Lyric \\ Result \\ : Soldiers injured and dying everyday \\ : Hyperbole}

From the lyric above, the narrator exaggerates that Soldiers injured and dying everyday. The words that contain hyperbole are represented by "dying everyday". In fact, the subject is not literally dying but is using hyperbole to figuratively communicate how hard the soldiers risk everything for the benefit of people in their country and to politicians in government.

\section{Poet 3 - The Black Cape}

Table 3 of The Black Cape

\begin{tabular}{|l|l|c|}
\hline No & Lyrics & Stanza \\
\hline \multirow{1}{*}{1} & I wear pain like a black cape, & 1 \\
\cline { 2 - 3 } & \begin{tabular}{c} 
I carry it like clouds carry rain. \\
\cline { 2 - 3 }
\end{tabular} & 1 \\
\cline { 2 - 3 } & $\begin{array}{c}\text { It disappears with your touch } \\
\text { whispering itself away like sand } \\
\text { in the wind. }\end{array}$ & 1 \\
\cline { 2 - 3 } & $\begin{array}{c}\text { Before darkness takes over my } \\
\text { brain }\end{array}$ & 1 \\
\hline
\end{tabular}

Data I

Lyric

Result

\section{: I wear pain like a black cape : Simile}

In this lyric there is a comparison between "pain” with " black cape.” It shows that, the man who feels terrific pain is like being forced to wear black cape. He does not get to choose when to put it on and take it off.It is a second skin which gradually seeps into his own real skin.

\section{Data II}

Lyric

Result

\section{: I carry it like clouds carry rain. : Simile}

From the lyric of "I carry it" can be defined the narrator assume that pain is something to carry, he feel his strength in the experience of pain. It is all in how he carry it. That is what matters, pain is a feeling. His feelings are a part of him, it is own reality. He should stand up for his right to carry his pain.

The phrase about "clouds carry rain", there is relation between clouds and rain. When water vapor rises in the sky it forms clouds. Then clouds get full with rain and become heavy they start pouring down in form of rain.

Based on explanation above, the writers conclude that the lyric above uses simile. Simile is explicit comparison of two things, using connective words. The poet compares the man who carry out of his pain like clouds carry rain, it is also using connective word.

\section{Data III}

I wear pain like a black cape,

I carry it like clouds carry rain.

Lyric $\quad$ : It disappears with your touch

Result : Hyperbole

These lyrics are explicitly hyperbole. It deals with implied meaning that the man who feels the pain just can be healed by therapy or treatment as well with doctor. The lyrics here does not mean that his girlfriend truly can be healing his pain, but the man assumes that his girlfriend support him so well, but sudden he feels like the wind that healing and the pain is disappear when he feels a touch of his girlfriend. 


\section{Data IV}

Lyric

: it disappear with your touch whispering itself away like sand in the wind.

Result : Simile

The phrase of "whispering" is referred to his girlfriend touch and "itself" is referred the pain. In the previous phrases of the lyric, the pain is disappear when his girlfriend touch him. the lyric of "whispering itself away like sand in the wind" can be defined that pain lost like sand in the wind. The pain as if like grains that lost because of carried by wind.

\section{Data V}

Lyric

Result

: Before darkness takes over my brain : Personification

The darkness a non-human thing is playing its part in the lyrics as if it is a human being. Work is an act that can only be done by a human. The word of "darkness" it is referred to death. The phrase of "take over" is the verb show an act that can only be done by human.

The meaning of the lyric is simply are trying to imply that darkness is not strong anymore and it is still talking about people who are having a depression they think that the only thing better than this is death.

The mostly of Figurative Language Types in Kelly Darrow's Poetry

From the result of this analyze shows that there are 16 the types of figurative language in Kelly Darrow's poetry consist of:

Table 4 of Analysis of the Result

\begin{tabular}{|c|c|c|c|c|c|}
\hline $\begin{array}{l}\mathrm{N} \\
\mathrm{o}\end{array}$ & $\begin{array}{l}\text { Poetry } \\
\text { Titles }\end{array}$ & Lyrics & S & $\mathrm{L}$ & $\begin{array}{l}\text { The Types of } \\
\text { Figurative } \\
\text { Language }\end{array}$ \\
\hline 1 & \multirow{5}{*}{$\begin{array}{c}\text { Charm of } \\
\text { Cobra }\end{array}$} & $\begin{array}{l}\text { She has the } \\
\text { sting of a } \\
\text { scorpion, and } \\
\text { the charm of a } \\
\text { cobra }\end{array}$ & 1 & 1 & Metaphor \\
\hline 2 & & $\begin{array}{c}\text { She acts like } \\
\text { your friend, } \\
\text { but she don't } \\
\text { know ya }\end{array}$ & 1 & 2 & Simile \\
\hline 3 & & $\begin{array}{l}\text { Her bite is } \\
\text { sexy, just } \\
\text { before the } \\
\text { poison }\end{array}$ & 2 & 7 & Irony \\
\hline 4 & & $\begin{array}{l}\text { The mastery } \\
\text { of her art, is } \\
\text { the beauty of } \\
\text { her seduction }\end{array}$ & 3 & $\begin{array}{l}1 \\
2\end{array}$ & Metaphor \\
\hline 5 & & $\begin{array}{l}\text { You end up } \\
\text { giving her } \\
\text { your life and } \\
\text { soul }\end{array}$ & 4 & $\begin{array}{l}1 \\
3\end{array}$ & Hyperbole \\
\hline 6 & Politician & $\begin{array}{c}\text { Spreading to } \\
\text { the } \\
\text { people like } \\
\text { cancers }\end{array}$ & 1 & 4 & Simile \\
\hline
\end{tabular}

\begin{tabular}{|c|c|c|c|c|c|}
\hline $\begin{array}{l}\mathrm{N} \\
\mathrm{O}\end{array}$ & $\begin{array}{l}\text { Poetry } \\
\text { Titles }\end{array}$ & Lyrics & S & $\mathrm{L}$ & $\begin{array}{l}\text { The Types of } \\
\text { Figurative } \\
\text { Language }\end{array}$ \\
\hline 7 & & $\begin{array}{l}\text { Crooked suits } \\
\text { on the hill }\end{array}$ & 2 & 5 & Understatement \\
\hline 8 & & $\begin{array}{l}\text { Homeless in } \\
\text { the street }\end{array}$ & 2 & 6 & Metaphor \\
\hline 9 & & $\begin{array}{l}\text { Doctor's and } \\
\text { their pills }\end{array}$ & 2 & 7 & Metaphor \\
\hline 10 & & $\begin{array}{l}\text { Working man } \\
\text { dead on his } \\
\text { feet }\end{array}$ & 2 & 8 & Hyperbole \\
\hline 11 & & $\begin{array}{c}\text { Soldiers } \\
\text { injured and } \\
\text { dying } \\
\text { everyday }\end{array}$ & 3 & 9 & Hyperbole \\
\hline 12 & \multirow{5}{*}{$\begin{array}{c}\text { The Black } \\
\text { Cape }\end{array}$} & $\begin{array}{c}\text { I wear pain } \\
\text { like a black } \\
\text { cape, }\end{array}$ & 1 & 1 & Simile \\
\hline 13 & & $\begin{array}{c}\text { I carry it like } \\
\text { clouds carry } \\
\text { rain. }\end{array}$ & 1 & 2 & Simile \\
\hline 14 & & $\begin{array}{l}\text { It disappears } \\
\text { with your } \\
\text { touch }\end{array}$ & 1 & 3 & Hyperbole \\
\hline 15 & & $\begin{array}{l}\text { whispering } \\
\text { itself away } \\
\text { like sand in } \\
\text { the wind. }\end{array}$ & 1 & 4 & Simile \\
\hline 16 & & $\begin{array}{c}\text { Before } \\
\text { darkness takes } \\
\text { over my brain }\end{array}$ & 1 & $\begin{array}{l}1 \\
3\end{array}$ & Personification \\
\hline
\end{tabular}

$\mathrm{S}=$ Stanza

$\mathrm{L}=$ Line

\section{CONCLUSION}

The conclusion is based on the statement of the problem which was mentioned on chapter I. Regarding the first problem, the writers takes McKenzie's theory to find out types of figurative language in the poetry. After the writers take the data and classify them based on their categories of figurative language, the writers conclude that the Kelly Darrow's Poetry use some figures of speech. They are: Simile, Metaphor, Personification, Hyperbole, Understatement, and Irony.

Regarding the second problem about the meaning of figurative language in Kelly Darrow's poetry, the writers find some information about it. The poetry talks about social life. The poetry conveys various messages. There is information and social life message behind the poetry. The meaning of figurative language found in Kelly Darrow's poetry was analyzed on the chapter of discussion. Based on the discussion on Chapter III, the figurative language that mostly found in the Kelly Darrow's poetry is simile. Simile gives to compare two different things object or a concept to add comparison intensity, otherwise merely informative statement of the poetry. 


\section{REFERENCE}

Arp, Thomas R and Greg Johnson. Perrine’s Sound and Sense: An Introduction to Poetry. New York: Harcourt College Publishers. 2000.

Dancygier, Barbara and Eve Sweetser. Figurative Language. New York: Cambridge University Press. 2014.

Darrow, Kelly. The American Dream Poetry Collection. Taken by: https://www.freeebooks.net/ebook/The-American-DreamPoetry-Collection (accessed on 6th June 2017) 2012.

Darrow, Kelly. Keith Kelly Write For Life. Taken by: hhtp/keithkelly1.weebly.com/poetry.html (accessed on 20th April 2017)

Kennedy, X J. And Dana Gioia. Literature: An Introduction to Fiction, Poetry, Drama, and Writing $\left({ }^{10 \text { th }}\right.$ edition). New York: Pearson Longman. 2007.

Kennedy, X J. And Dana Giola. Handbook of Literary Terms: Literature, Language, Theory. New York: Pearson Longman. 2005.

McKenzie, Pamela Walker. Interactive Notebook Language and Arts. USA: Carson- Dellosa Publishing. 2016.

Moleong, Lexy J. Metode Penelitian Kualitatif. Bandung: Remaja Rosdakarya. 2007.

Peterson. Master The GED. USA: Peterson's Publishing, A Nelnet Company. 2012.

Robinson, Daniel. William Wordsworth's Poetry. New York: Continuum International Publishing Group. 2010.

Tjahyono, Tengsoe. Mendaki Gunung puisi ke arah kegiatan apresiasi. Malang: Bayumedia Publishing. 2011.

\section{PROFILE OF THE WRITERS}

Cicih Nuraeni was born in Ciamis, West Java, on February 24, 1987. She is the youngest child from two.
She completed the elementary school in SDN Kawunglarang II, Rancah Ciamis and graduated in 1999. Then continued her study in SLTPN 1 Rancah and graduated in 2002. In 2005, the author completed his studies at SMA Negeri 1 (SMAN 1) North Cikarang, Bekasi. Then she took the Diploma Program in Academy of Foreign Language Bina Sarana Informatika Jakarta (ABA BSI Jakarta) in English Department and graduated in 2008. In 2007, she started join with Oxford Course Indonesia as an English Tutor and Teaching for Elementary Level (TK), basic level (SD), and Advanced Level (Junior and Senior High School). In 2009, she joined Academy of Foreign Language Bina Sarana Informatika Jakarta (ABA BSI) as an Assistant Lecturer and at the end of 2009 became English Instructor in Language Laboratory. She taught Teaching English as Foreign Language (TEFL), Business Correspondence, Interpreting, Pronunciation Drills, and Pre-intermediate Grammar. In the same year, the writers went on to Strata-1 at the University Indraprasta PGRI (UNINDRA) in English Department and graduated in 2011. In 2012, the writers continued her study to Study Strata-2 at the University Indraprasta PGRI (UNINDRA) at Department of Language Education and graduated in 2014. From 2015 up to now, she joins and teaches at STIBA Nusa Mandiri, Ciputat South Tangerang. Besides teaching, she also join with Indonesian Lecturer Assossiation (ADI) as a member.

Putri Amalia Peron was born in Jakarta, $20^{\text {th }}$ September 1996. She Lived in Jalan Tanjung Pura II No. 109 Jakarta Barat. She graduated from SDN 04 Pegadungan at 2008. Then she continued the study to SMPN 186 Jakarta and graduated at 2011. She took study at SMAN 56 Jakarta and graduated at 2014. Then took English Major in Akademi Bahasa Asing BSI Jakarta and graduated at 2017. Putri also had an experience as Warehouse Staff at PT. Putra Tanjung Jaya from 2015 to 2016. Then she worked at PT. Kresna Reksa Finance as Administration Staff from 2016 until now. 